УДК

DOI:

Корнель Сятецький, професор, завідувач кафедри народних музичних інструментів та вокалу Дрогобицького державного педагогічного університету імені Івана Франка, заслужений працівник освіти Украӥни

\title{
НАЦІОНАЛЬНА СПРЯМОВАНІСТЬ ТВОРЧОСТІ ВИДАТНОГО УКРАЇНСЬКОГО СПІВАКА ІВАНА КОЗЛОВСЬКОГО
}

У статті об 'єктивно висвітлюється органічний зв 'язок виконавської діяльності видатного співака I. Козловського з украӥнськими композиторами, українською народною піснею. Зібрані факти із життя й творчості співака демонструють його великий патріотизм, безмежну любов до своєї Вітчизни, свого народу. Водночас зроблено спробу розкрити трагічність творчої особистості художника-виконавия в умовах тоталітарної системи. Висвітлюється репертуар співака, його захоплення украӥнським вокальним мистецтвом, роль і місие української пісні у творчій діяльності мития.

Ключові слова: Іван Козловський; оперно-камерний співак; репертуар; творча спадщина; пісня; коляда; арія.

Jim. 9.

Kornel Syatetskiy, Professor, Head of the Folk Musical Instruments and Vocal Performance Department Drohobych Ivan Franko State Pedagogical University Distinguished Educator of Ukraine

\section{NATIONAL DIMENSION IN THE CREATIVE ACTIVITY OF IVAN KOZLOVSKIY - A PROMINENT UKRAINIAN SINGER}

The article objectively describes the organic connection between performance activity of the prominent Ukrainian singer Ivan Kozlovskiy with Ukrainian composers and Ukrainian folk singing. Facts derived from life path and creative heritage of Ivan Kozlovskiy showcase his immense patriotism, his boundless love towards his native turf, his great respect for his nation, his love to his mother tongue and to songs written in it. The author emphasises how important it is for a person to realise and come to terms with his or her own national identity, particularly as far as emigry environments are concerned. The individual's personality is crucially impacted by the system of his or her upbringing and background, by the atmosphere of relations in one's family, everyday life etc. Ivan Kozlovskiy was brought up in a traditional Ukrainian family wherein love, mutual respect, and overall Christian values were predominant. During the twenty four years Ivan Kozlovskiy spent in Ukraine, he managed to shape his personality and to forge himself into a singer possessing clear national and ethnic identity. These traits pertained to Ivan Kozlovskiy throughout his entire life.

In addition to the above, an attempt has been made to reveal the tragic dimension of the creative personality of a performing artist trying to function in the circumstances of a totalitarian regime. Plenty of Ivan Kozlovskiy's records had not been republished for over half a century. Russian factbooks and reference books never forget to mention that Ivan Kozlovskiy was a prominent representative of the Russian school of vocal singing - they do, however, downright omit the fact that he was, as a matter of fact, performing musical works by Ukrainian composers. A number of his works had been banned from public performances; vinyl recordings of Ivan Kozlovskiy performing kolyadas, Ukrainian Christmas carols, were systematically destroyed. He never had a chance to perform on major global stages outside the Soviet Union. And his last will and testament with a request to be buried on his native turf was also never respected. As of today, the Ukrainian society is presented with an extraordinarily important task: to assemble and put together its national heritage, breadcrumb by breadcrumb, little by little, piece by piece.

Keywords: Ivan Kozlovskiy; opera and chamber singer; repertoire; creative heritage; a song; kolyada; an aria.

П остановка проблеми. Українська земля багата на таланти. 3 їі надр вийшла ціла плеяда науковців, вчених, митців, політиків, спортсменів, здобутки яких стали надбанням для усієї світової спільноти. Висока музична обдарованість українського народу сприяє особливому статусу України в світі, адже українці вважаються однією $з$ найспівучіших націй, поряд з італійцями.

Одним 3 яскравих представників співаків

С К. Сятецький, 2019 світової слави $є$ видатний українських тенор XX ст., класик світового вокального мистецтва, творець неповторних образів усвіті оперного та камерного виконавства Іван Козловський.

Виконавський геній дозволяє ввести його ім'я до когорти видатних зірок вокального мистецтва, пов'язаних зі становленням та кристалізацією кращих традицій світової вокальної школи. Вивчаючи його творчість і мистецьку діяльність, із захопленням відзначаємо його національну 


\section{НАЦІОНАЛЬНА СПРЯМОВАНІСТЬ ТВОРЧОСТІ ВИДАТНОГО УКРАЇНСЬКОГО СПІВАКА ІВАНА КОЗЛОВСЬКОГО}

спрямованість, постійний зв'язок із рідною Батьківщиною, з краєм, де проходили дитячі та юнацькі роки, де формувався мистецький геній співака.

Аналіз основних досліджень та публікацій. Зацікавленість дослідників цією визначною мистецькою постаттю спостерігаємо у працях музикознавців Т. Булат, І. Лисенка,Ю. Станішевського, С. Козака, О. Радутної та ін.

Вагомими джерелами вивчення творчості I. Козловського $є$ мемуарна праця самого співака “Музика - радість і мій біль”, статті В. Тольби, В. Лебедєва, Б. Гнидя, М. Рейзена, Н. Обухової, А. Чернова, проте у них доволі фрагментарно привертається увага саме до національних почувань і напрямків творчої діяльності співака.

Мета статті полягає в розкритті величі синівської любові співака Івана Козловського, його поваги до народу, рідної землі, любові до рідного слова, пісні; у розкритті важливості усвідомлення своєї національної ідентичності, особливо перебуваючи поза межами рідної країни; у висвітленні взаємовпливів упрофесійній діяльності митця з українським вокальним мистецтвом, ролі і місця української пісні у творчій діяльності митця.

Виклад основного матеріалу. На формування особистості вирішальний вплив має система виховання, атмосфера взаємовідносин у сім'і, побуті, тощо. Іван Козловський зростав у традиційній українській родині, де панувала любов, взаємоповага, тобто християнські засади. Мати, прищеплюючи синові віру та любов до Всевишнього й людські чесноти, мріяла, щоб він став священиком.

Від 1907 до 1917 року малий Іван співав у хорі при Свято-Михайлівському соборі. Згодом став солістом академічного хору, яким керував видатний диригент Олександр Кошиць. Розуміючи, що перед ним справжній самородок 3 поставленим від природи голосом, О. Кошиць скерував хлопця до відомої колишньої співачки імператорського театру, викладачки співу в Київському музично-драматичному інституті, зорганізованого Миколою Лисенком, Олени Муравйової. У цієї знаменитої співачки і великого педагога юнак навчався два роки (1917 - 1919).

У бібліографічному досьє “Їх поріднив полтавський край” дослідниця Олена Радутна цікаво описує зустріч юного Івана з М. Лисенком. “Якось він (Лисенко - К. С.) гуляв Голосіївським лісом і почув, як десь у гущавині хлопчик співає “Ой ходила дівчина беріжком, заганяла селезня батожком...” Лисенко підійшов ближче і бачить: стоїть такий собі хлопчина і дивиться на нього злякано. Маестро і каже: "Не батожком, хлопче, а батіжком. Українське слово святе, на хресті було розп'яте. Не травмуй його, не каліч. Це гріх великий. А ти будеш знаменитим" $[5,21]$.

Значний вплив на формування національної свідомості майбутнього співака мало спілкування 3 відомими театральними діячами товариства драматичних артистів Панасом Саксаганським, Марією Заньковецькою, Іваном Мар'яненком, Любов’ю Линицькою.

Позитивну роль у формуванні митця відіграв Полтавський період його творчості (1919-1924). В оперному театрі ім. М. Гоголя Козловський виконував партію Петра ("Наталка Потавка" М. Лисенка), Дубровського (“Дубровський” Е. Направник), Йонтека ("Галька" С. Монюшко), Герцога (“Ріголетто" Дж. Верді), Ленського (“Свгеній Онєгін” П. Чайковського), Лоенгріна (“Леонгрін” Р. Вагнера). У 1924 році співак вступив до трупи Харківського оперного театру. Блискучий дебют у “Фаусті” (Ш. Гуно) дозволив йому зайняти провідне положення у трупі. Та через рік, відкинувши вельми престижне запрошення у Маріїнський (Ленінградський) оперний театр, артист переїжджає до Свердловська. Від 1926 до 1954 року I. Козловський - соліст Великого театру в Москві [6, 25].

Двадцять чотири роки життя I. Козловського в Україні - це роки формування його як особистості, співака з чіткою національною свідомістю. І ці риси знаменитий українець, видатний співак I. Козловський проніс протягом всього свого життя.

Блискучий знавець української музики, I. Козловський активно пропагував творчість М. Лисенка, Я. Степового, К. Стеценка, М. Аркаса, С. Гулака-Артемовського. У його репертуарі була велика кількість українських народних пісень, українських вокальних шедеврів, записаних у сольному виконанні, дуетом та тріо, з хорами, ансамблями, оркестрами.

Аналізуючи творчість великого співака, його фонозаписи, звертаємо увагу на те, що в одному 3 чотирьох дисків міститься 18 записів арій із українських опер М. Лисенка, С. ГулакаАртемовського, унікальні романси М. Лисенка на вірші Т. Шевченка “Мені однаково”, “Огні горять”, українські народні пісні, цикл українських коляд: “ІІе звізда чудна”, “Ігор-цар”, “Добрий вечір”, "Нова рада", "По всьому світу стала новина". Збереглися й стали безцінними унікальні записи перлин української творчості “Коли розлучаються двоє”(М. Лисенко, Г.Гейне) зМ. Гришком, А. Івановим і Б. Гмирею, “Де ти бродиш моя доле” (М. Кропивницький) з М. Михайловим, “Ой уполі 


\section{НАЦІОНАЛЬНАСПРЯМОВАНІСТЬ ТВОРЧОСТІ ВИДАТНОГО УКРАЇНСЬКОГОСПІВАКА ІВАНА КОЗЛОВСЬКОГО}

вітер віє” з Б. Гмирею, “І широкою долиною”, “Скажи мені правду” з О. Басистюк, “Я другої не любив тай любить не буду” з Л. Фірстовою, “Ой дівчино, шумить гай” (укр. нар. пісня - тріо 3 Г. Ковальовою, та Д. Кадніковим).

До творчого доробку співака ввійшли українські оперні партії: Петра та Левка $з$ опер "Наталка Полтавка" та "Утоплена" М. Лисенка, Андрія з опери “Запорожець за Дунаєм” С. ГулакаАртемовського, Андрія $з$ опери “Катерина" М. Аркаса.

Тодішня тоталітарна влада створювала різні перепони для пропаганди української музики, пісні. Особливо жорстко можновладці реагували на видання фірми грамзапису “Мелодія” у 1973 році. У серії платівок "Искусство Козловского", поряд 3 романсами, творами 3 опер "Наталка Полтавка" М. Лисенка, С. ГулакаАртемовського, було записано п'ять колядок у блискучому виконанні співака, сестер Каріни та Рузани Лісиціан у супроводі Великого хору радіо (худ. керівник К. Птіца) та оркестру Великого театру СРСР (диригент I. Гусман).

Ця платівка, яка дивом з'явилася і в Україні, стала раритетом, прикрасою колекцій меломанів й користувалася великою популярністю. Пригадую, як я та мої друзі жадібно слухали записи цих популярних автентичних колядок у такому високопрофесійному і високомистецькому виконанні. Влада, побачивши такузагальновизнаність записів, наказала їх знищити. Тільки у Львові на складах було потрощено близько 400 платівок.

Працюючи провідним солістом Великого театру в Москві (1926 - 1954), продовжуючи активне концертне життя поза межами театру, I. Козловський постійно зберігав тісні зв'язки 3 Україною, яка завжди займала найважливіше місце у його житті й серці. Титанічні зусилля знадобились співакові, щоб за свої власні кошти відкрити у рідному селі Мар'янівка Київської області дитячу музичну школу в 1972 році. Щорічною традицією були його виступи у Києві на урочистостях 3 нагоди величних святкувань днів пам'яті Т. Шевченка $[2,26]$.

Проживши довге, активне творче життя, досягнувши видатних виконавських успіхів, чи був I. Козловський щасливою людиною? Володіючи найвищими урядовими нагородами тоталітарної системи: Герой Соціалістичної праці, двічі лауреат Сталінської премії $(1941,1949)$, Державної премії УРСР ім. Т. Шевченка (1990), народний артист СРСР (1940), народний артист України (1993), володар 5 орденів Леніна та ордену “Знак Пошани" - як особистість, митець, художник I. Козловський у жорстокій, тоталітарній системі став співцем, якого посадили у “золоту клітку”. Крім поодиноких виступів у Румунії, Чехословаччині, Німеччині на Потсдамській конференції, Цейлоні (Шрі Ланка), ангажементу на партію Рудольфа (“Богема" Дж. Пуччіні) у Відні, в світі І. Козловський не виступав, був невідомий пересічному слухачеві. Хоча співак мріяв про поїздки в Свропу, відвідання знаменитого “Ла Скала” (оперний театр в Мілані), глибше ознайомлення зі світовою мистецькою культурою, живописом, архітектурою, досягненням оперного мистецтва. Однак, не судилося, І. Козловський був “невиїзним” митцем.

3 цієї причини побутує легенда про те, як I. Козловський звернувся до Сталіна з проханням: - “Я ніколи не їздив за кордон. Хотілось би з’їзити.

- Не втечем?

- Що ви, тов. Сталін, рідне село мені набагато дорожче, ніж вся заграниця.

- Правильно, молодець. От і їдь у рідне село" $[3,17]$.

Митцям, поетам, творчій інтелігенції було особливо важко у тоталітарній, підневольній системі розвиватись, створювати мистецькі шедеври в галузі літератури, живопису, музики. За спогадами доньки співака Анастасії, Козловський жив 3 відчуттям несприйняття, незрозумілості. “Десь в глибині душі його поселилася Велика Печаль. Йому здавалось, що його не розуміють... рідні і близькі, держава, чиновники, з ними у нього завжди були непрості відносини" $[7,89]$.

Неодноразово $з$ невідомих причин поступала заява з вищих ешелонів партійної влади - “цього співати не можна": в 1941 році ЦК КПРС зупинило трансляцію різдвяної коляди у виконанні I. Козловського; на відкритті Київського домумузею поета М. Рильського І. Козловському заборонили співати пісню “Ой уполі криниченька”; в 1973 - знищили частину накладу платівки.

У розквіті творчих сил, у віці 54 років, через розбіжності $з$ керівництвом і незадоволенням репертуарною політикою, митець назавжди покинув Великий театр, хоча на сцені продовжував виступати ще понад 30 років (до 1989 року). Переважно артисту нав'язували ті чи інші ролі, не враховували його побажання, право вибору репертуару.

Перелік оперних партій співака нараховує близько 50, 3 них - тільки 11 партій західноєвропейських композиторів. Для співака такого масштабу з такими феноменальними вокальними даними (особливо верхнім регістром) цих партій доволі мало. Безумовно, якби співакові 


\section{НАЦІОНАЛЬНАСПРЯМОВАНІСТЬ ТВОРЧОСТІ ВИДАТНОГОУКРАЇНСЬКОГОСПІВАКА ІВАНА КОЗЛОВСЬКОГО}

були створені вільні умови праці, він збагатив би свій оперний репертуар шедеврами західноєвропейської та світової класики, став бизіркою світового оперного мистецтва. Як говорив О. Гончар “І. Козловський - епоха в нашому мистецтві” [5, 19].

Своєю повсякденною працею і помислами він постійно був пов'язаний з Україною, рідною Мар'янівкою, друзями. Співак взяв під опіку створення Меморіального музею М. Лисенка у Києві, відіграв значну роль у формуванні в Києві музею М. Заньковецької. Щороку приїздив до Канева - вклонитись великому Пророку, приїздив iз колегами-співаками до рідної Мар'янівки, 3 якими виконував твори на слова Т. Шевченка. Коли місцеві владці намагалися спілкуватися 3 ним російською, перебивав 3 іронічною посмішкою: “Що це ви до мене російською говорите? Я рідної мови не забув!” Щоразу говорив: "Приїхав попращатися 3 моєю рідною Україною" [1].

Звичайно, “мар'янівці завжди були бажаними гостями в московській квартирі співака. Коли земляки переступали її поріг, він кричав своїм домашнім: "Москалі - геть від мене!" - і відразу садив всіх за стіл годувати, незалежно від того, п'ять чоловік приїхало, чи п'ятдесят. Сім'я Козловського ностальгію Івана Семеновича по Україні терпіла, але не підтримувала" [9, 6].

Ганна Козловська у передмові до книги батька "Музика - радість і мій біль - пише: "З Україною, своєю Батьківщиною, батько був пов’язаний непорушним душевним зв'язком все своє життя, до самого кінця. Він любив Україну віддано і ніжно - синівською любов’ю. Любив її звичаї, природу, мову (часто говорив зі своєю сестрою українською). Батько зібрав і обробив українські колядки і був унікальним виконавцем української народної пісні” [7, 4].

I. Козловський упродовж довгого творчого життя щедро дарував людям радість, почуття любові, доброти, створюючи високохудожній образ героя оперної арії, романсу, чарівної народної пісні. Пригадую далекі 1980-ті роки, коли у гості до Франкового вузу в Дрогобичі завітав цей великий артист. Пам'ятаю повний аншлаг в актовій залі, загальне збудження слухацької аудиторії зустріччю з видатною особистістю і ті чарівні звуки високого вокального мистецтва! А 3 якою наснагою, піднесенням, майстерністю супроводжував спів славний піаніст, мій незмінний концертмейстер Володимир Баб'як! Як найдорожчу реліквію зберігаю гуртове фото 3 I. Козловським, керівництвом інституту та прихильниками його великого таланту біля пам'ятника I. Франкові.
У щоденнику І. Козловського $є$ такі слова: “В чому щастя? Віддати те, що маєш. I віддавай швидше... В цьому, напевне, взаємне збагачення" $[3,17]$. Митець щедро віддавав людям свій талант і радість, а Україні - синівську любов. У цьому, мабуть, митець був щасливим, а Всевишній дарував йому довгих років життя.

I. Козловський був глибоковіруючою людиною. Його можна назвати охоронцем традицій, деякі 3 них він створював сам. У нього завжди вдома стояла китиця колосків. Він дарував колоски всім, кого знав - по випадку і просто так. Обов'язково приносив колосок на похорон друзів і рідних - клав у труну. Зерно - євангельський образ, символ вічного життя" [4, 21].

Радянською і нинішньою московською владою робилось і робиться все, щоб викреслити українські сторінки з творчої біографії співака. Чимало його записів не перевидавались понад півстоліття. У російських довідниках і біографічних виданнях не згадується, що I. Козловський виконував твори українських композиторів та українські пісні, хоча як зазначалось вище, в репертуарі співака понад 100 українських вокальних шедеврів. У біографічних виданнях зазначається, що I. Козловський (який переїхав у Москву вже сформованим, відомим співаком, солістом Харківського та Саратовського оперного театрів у віці 26 років) $є$ яскравим представником російської вокальної школи. В останні роки шовіністичне нахабство перейшло всі межі - у Москві співакові вже навіть змінено національність. Він тепер не “радянський”, а “русский певец”. Воля Івана Козловського бути похованим в рідній Мар'янівці також виконана не була, адже цей видатний українець, митець-патріот знайшов свій останній прихисток на Новодівичому цвинтарі в Москві.

Та пам'ятають, люблять і шанують в Україні свого генія. У Мар'янівці створено Меморіальний музей I. Козловського, на території якого споруджено пам'ятник, зведено монумент співакові й у Києві. На Хрещатику діє концертний зал ім. Івана Козловського. На одній із будівель Михайлівського Золотоверхого монастиря встановлена меморіальна дошка на вшанування пам'яті великого українського співака [1].

Доволі часто в Україні відбуваються різноманітні культурні заходи, присвячені пам'яті видатного співака. Примітно, що в одномуз таких вечорів 5 травня 2017 року в Мистецькоконцертному центрі ім. Івана Козловського із програмою "Музика крізь століття" виступив баритон Віктор Янковський (випускник Дрогобицького музичного коледжуім. В. Барвінського, 


\section{НАЦІОНАЛЬНАСПРЯМОВАНІСТЬ ТВОРЧОСТІ ВИДАТНОГО УКРАЇНСЬКОГО СПІВАКА ІВАНА КОЗЛОВСЬКОГО}

клас вокалуК. Сятецького, Львівської Національної музичної академії ім. М. Лисенка, стажист вокальної студії у м. Пезаро (Італія). До програми талановитого молодого співака ввійшли: куплети Тореадора Ескамільо (з опери Ж. Бізе “Кармен”), арія Дон Жуана (з опери В.-А. Моцарта “Дон Жуан”), арія Ренато (з опери Дж. Верді “БалМаскарад”), арія Фігаро (з опери В.-А. Моцарта “Весілля Фігаро”), романси С. Рахманінова, П. Чайковського, А. Кос-Анатольського, українські народні пісні.

Як зазначила у рецензії директор Мистецькоконцертного центру Тетяна Зозуля, концерт пройшов 3 великим успіхом, і став яскравим заходом відзначення пам'яті великого співака [8]. Такі програми є яскравим прикладом невмирущої пам'яті про Івана Козловського, доводять всенародну любов і шану до цієї видатної особистості, дають змогу молодій генерації виконавців-співаків шліфувати свою майстерність перед вимогливим, високоінтелектуальним слухачем.

Висновки. Підсумовуючи, варто наголосити на важливості для кожної людини, а особливо, для митця, зберігати невмирущу любов, повагу до рідного слова, пісні, рідного краю, рідної Вітчизни. Багато сторіч бездержавності недруги нашої держави нещадно експлуатували як матеріальні, так і духовні багатства нації. Російська імперія, Польща інші “сусіди” присвоювали собі імена відомих вчених, поетів, письменників, митців. У час становлення нашої незалежної держави стоять архіважливі завдання для українського суспільства - збирати по крупинці свої розпорошені, розграбовані національні багатства, виховувати у молодого покоління велику гордість, шану і любов до особистостей незаслужено забугих, недооцінених уїхніх помислах, прагненнях і діяннях во ім'я своєї матері-Вітчизни - України.

\section{ЛІТЕРАТУРА}

1. Бондаренко О. Іван Семенович Козловський. URL: http://ridna.ua/2018/03/24-bereznya-1900-rokunarodyvsya-velykykj-ukrajinskyj-spivak-ivankozlovskyj/

2. Булат Т. Українські народні пісні та романси I.C. Козловського. Народна творчість та етнографія. 1980. № 3. С. 25-28.

3. Воинский Т. Так говорят о великом Певце Иване Козловском его современники и последователи. URL: http://tumentoday.ru/2011/03/ $\underline{18}$

4. Жежера В. Іван Козловський не розмовляв про буденні справи біля рояля. Украӥна. 2010. №3. C. 21 .
5. Їхпоріднив полтавський край: біобібліографіячне досьє / Упорядник О. Радугна; Полтавська обласна бібліотека для юнацтва ім. Олеся Гончара. Полтава, 2017. С. 12.

6. Козак С. Вічний жайвір. Повість про життя та творчий шлях видатного співака, сина України, Івана Семеновича Козловського. Київ, 2001. 206 с.

7. Козловський И. Музыка - радость и боль моя. Москва, 1992. 198 с.

8. Меморіальний музей-садиба I. С. Козловського. URL: http://kozlovskiy-is.at.ua/

9. Пятериков С. Велике місто Васильків. Дзеркало Тижня. 2002. № 378.

\section{REFERENCES}

1. Bondarenko, O. Ivan Semenovych Kozlovskyi [Ivan Semyonovich Kozlovskyi]. Available at: http:// ridna.ua/2018/03/24-bereznya-1900-rokunarodyvsya-velykykj-ukrajinskyj-spivak-ivankozlovskyj/ [in Ukrainian].

2. Bulat, T. (1980). Ukrainski narodni pisni ta romansy I. S. Kozlovskoho [Ukrainian folk songs and romances of I. S. Kozlovskyi]. Folk art and ethnography, Vol. 3, pp. 25-28. [in Ukrainian].

3. Voinskiy, T. Tak govoryat o velikom Pevtse Ivane Kozlovskom ego sovremenniki i posledovateli [His contemporaries and followers so speak about great singer Ivan Kozlovskyi]. Available at: http:// tumentoday.ru/2011/03/18. [in Russian].

4. Zhezhera, V. (2010). Ivan Kozlovskyi ne rozmovliav pro budenni spravy bilia roialia [Ivan Kozlovskyi isn't talking about everyday things at the piano]. Ukraine, Vol. 3, p. 21. [in Ukrainian].

5. Yikh poridnyv poltavskyi krai: biobibliohrafichne dosie (2017). [Theirnative Poltava region: biobibliografy dossier]. Editor O. Radutna; Poltava Oles Honchar regional library for youth. Poltava, p. 12. [in Ukrainian].

6. Kozak, S. (2001). Vichnyi zhaivir: [Povist pro zhyttia ta tvorchyi shliakh vydatnoho spivaka, syna Ukrainy, Ivana Semenovycha Kozlovskoho]. Eternal Skylark: a tale about the life and career of the famous singer, son of Ukraine Ivan Semenovich Kozlovskyi. Kyiv, 206 p. [in Ukrainian].

7. Kozlovskiy, I. (1992). Muzyika - radost i bol moya [Music - happiness and pain is my]. Moskva, 198 p. [in Russian].

8. Memorialnyi muzei-sadyba I. S. Kozlovskoho [Memorial Museum of I. S. Kozlovskyi]. Available at: http://kozlovskiy-is.at.ua// [in Ukrainian].

9. Piaterykov, S. (2002). Velyke misto Vasylkiv [Big city Vasilkov]. Mirror of the week, Vol. 378, p. 6. [in Ukrainian].

Стаття надійшла до редакції 12.03.2019 